ISSN 1392-3196 / e-ISSN 2335-8947

Zemdirbyste-Agriculture, vol. 101, No. 2 (2014), p. 169-176

DOI 10.13080/z-a.2014.101.022

\title{
Drying of forage grass seed harvested at different maturity and its utility value in autumn and spring sowing time
}

\author{
Rade STANISAVLJEVIĆ ${ }^{1}$, Dragoslav DJOKIĆ ${ }^{2}$, Jasmina MILENKOVIĆ 2 , Dragan TERZIĆ2, \\ Vladeta STEVOVIĆ ${ }^{3}$, Dalibor TOMIĆ ${ }^{3}$, Dejan DODIG ${ }^{4}$ \\ ${ }^{1}$ Institute for Plant Protection and Environment \\ Belgrade 11000, Republic of Serbia \\ E-mail: stanisavljevicrade@gmail.com \\ ${ }^{2}$ Institute for Forage Crops, Republic of Serbia \\ ${ }^{3}$ University of Kragujevac, Republic of Serbia \\ ${ }^{4}$ Maize Research Institute Zemun Polje, Republic of Serbia
}

\begin{abstract}
Tall fescue (Festuca arundinacea Schreb.), red fescue (Festuca rubra L.) and cocksfoot (Dactylis glomerata L.) are important fodder grasses, but in seed production, they are prone to seed shedding and certain yield losses. In practice, seeds are usually harvested at approximately 20-35\% moisture content and then are additionally dried to the moisture content of $12 \%$ or lower. However, to prevent shedding, seed was harvested at $45 \%$ moisture content. The effects of drying temperatures of $70,60,50,40,30$ and $22{ }^{\circ} \mathrm{C}$ on germination and dormancy of tall fescue, red fescue, cocksfoot seeds, harvested at moisture contents of 45,35 and $25 \%$, were observed in the present study. The analysis was done immediately upon seed drying, then three, eight and fourteen months later, which corresponds to the autumn and spring sowing time in the continental part of central and south-eastern Europe. In all the three species, drying temperature of $70^{\circ} \mathrm{C}$, regardless of the moisture content, and $60^{\circ} \mathrm{C}$ in the combination with a seed moisture content of $45 \%$, reduced germination. After three months, the highest germination was detected in tall fescue harvested at seed moisture of $25 \%$ and dried at $50^{\circ} \mathrm{C}$. Furthermore, the greatest germination in red fescue and cocksfoot was determined in seeds harvested with the moisture content of $35 \%$ and dried at $50^{\circ} \mathrm{C}$. After eight months, the highest germination in tall and red fescue were determined in seeds harvested with the moisture content of $25 \%$ and dried at $40-50^{\circ} \mathrm{C}$, while corresponding values in cocksfoot amounted to $25 \%$ and $22-30^{\circ} \mathrm{C}$, respectively. A positive and significant correlation was established between seed germination and seedling vigour.
\end{abstract}

Key words: Dactylis glomerata, drying temperatures, Festuca arundinacea, Festuca rubra, germination and dormancy, moisture.

\section{Introduction}

Plants of the genus dactylis and fescue are important for the production of forage and energy in region of central and south-eastern Europe (Kanapeckas et al., 2011; Samuil et al., 2012; Tilvikienè et al., 2012). However, there has been a decreasing trend of forage grass seed production in Europe (Huyghe, 2010). The main reasons for this are rising prices of cereals (wheat, barley and others). A greater income is obtained by grain production than by seed production of grasses. And therefore, these two productions are competitors for acreages (Jensen, 2010). Due to highly variable yields and low prices of grass seed, on the one hand, and the increased price of wheat, on the other hand, farmers use these areas for the growth of small grains, especially wheat, which has lead to grass seed shortage (Jensen, 2010). For the reason of economic sustainability of fodder grasses production it is necessary to achieve higher and more stable yields. This can partly be accomplished by preventing the loss of seeds resulting from shedding. However, it is often unavoidable since the emergence of generative stems of the same plant is uneven and the differences are even more pronounced in the production plots, leading to uneven seed maturation.

Fodder grasses are harvested when the seed moisture content is $20-35 \%$, whereby seed loss due to shedding can be up to $16.7 \%$ (Stanisavljević et al., $2010 \mathrm{~b}$ ). In order to prevent yield losses by shedding it is possible to harvest seeds with a higher moisture content. In addition to preventing seed shedding, harvest of seeds with a greater moisture content is practiced when the crop is tangled and lodged and when the weather at harvest is cloudy and rainy. After harvesting, seeds are dried to moisture of $12 \%$ or lower. It is done either naturally (conventionally) or in dryers at various temperatures. 
Drying temperatures in dryers can result in the reduction of seed dormancy (Stanisavljević et al., 2012; 2013), but can also affect protein stability, enzymic activities, damage of cell membranes and mitochondria, which can lead to the seed germination reduction (Bewley, Black, 1994).

Tall fescue is characterised by high adaptability to stress environments (Pecetti et al., 2011), while cocksfoot is particularly tolerant to high temperature stress (Annicchiarico et al., 2011). However, little is known about the effects of temperature stress during drying on the seed of these species. The objectives of the present study were as follows: i) to observe the effects of different drying temperatures on seed germination and dormancy of tall fescue, red fescue and cocksfoot harvested with moisture contents of 45,35 and $25 \%$; ii) to test the viability of seeds in different sowing times applied in the continental part of central and southeastern Europe.

\section{Material and methods}

The experiment was set up with commercial seeds of tall fescue (Festuca arundinacea Schreb.) cultivar K-20, red fescue (Festuca rubra L.) cultivar K-14, and cocksfoot (Dactylis glomerata L.) cultivar K-40. All three are summer-active (continental) cultivars and have been developed in Serbia from local populations. Three different seed lots (L) were used from commercial production in eastern (L1), central (L2) and south-eastern (L3) Serbia in 2010 and 2011. Sampling was done during June when the determined seed moisture (M) content amounted to 45, 35 and $25 \%$. In both years, there was a slow, steady ripening without extreme temperatures or the threat of excessive rainfall. There was up to $10 \%$ of the seed mechanically damaged when harvested at $45 \%$. A total of $25 \%$ and $9 \%$ seeds of tall fescue harvested with the moisture contents of $45 \%$ and $35 \%$, respectively were in the milk stage, while seeds with the moisture content of $25 \%$ were completely $(100 \%)$ in the dough stage. On the other hand, 23, 8 and $1 \%$ seeds of red fescue harvested with the moisture content of 45,35 and $25 \%$, respectively, were in the milk stage. In cocksfoot, 20, 7 and $1 \%$ of harvested seeds with the moisture content of 45,35 and $25 \%$, respectively, were in the milk stage. After sampling, seeds were dried either in the dryer at the following temperatures (T): 70, $60,50,40$ and $30{ }^{\circ} \mathrm{C}$ or conventionally on the floor at an average temperature of $22^{\circ} \mathrm{C}$. Drying was performed until the seed moisture content reached $12 \%$ and then 1000-kernel weight was determined.

Germination and dormancy were determined after four periods: immediately after drying, three, eight and fourteen months after drying. Three, eight and fourteen months' periods were chosen as they corresponded to the sowing time in autumn of the same year when the harvest was performed, and the sowing time in spring and autumn of the following year when the harvest was done, respectively. Germination and dormancy of seeds were determined in the laboratory of the Institute for Forage Crops, Kru evac, Serbia. In brief, seeds were chilled for five days at the temperature of $5^{\circ} \mathrm{C}$, and at the altering temperature $\left(25 / 15^{\circ} \mathrm{C}\right.$ light/ dark (8/16 h)). Final germination (\%) and dormancy (\%) of seeds were read in four replicates $(4 \times 100$ seeds $)$ on filter paper after 14 days for tall and red fescue and after 21 days for cocksfoot according to the ISTA rules (ISTA, 2011). Tetrazolium test was performed with ungerminated seeds with the intention of separation dormant from dead seeds. The primary root length $(\mathrm{cm})$, shoot length $(\mathrm{cm})$ and fresh seedling biomass (root + shoot, $\mathrm{mg}$ ) were also measured after the final count for normal seedlings.

Data were subjected to the analysis of variance, in a factorial arrangement with five factors (year, seed lot, seed moisture, drying temperature and seed maturation (SM) period) for final germination and seed dormancy. The means were compared with the LSD multiple range test at the $5 \%$ level of probability. To correct for non-normality the statistical analysis was done on arcsine transformed values. The relationships between final germination and seedling traits were analysed by determining Pearson's correlation coefficients.

\section{Results}

On average, for all three species, seeds harvested with the moisture content of $45 \%$ had the lowest 1000-kernel weight, while seeds harvested with the moisture content of $25 \%$ had the highest 1000 -kernel weight. However, the differences were not statistically significant (Table 1).

Table 1. 1000-kernel weight (g) (averaged over lots, years and drying temperatures)

\begin{tabular}{lccc}
\hline \multirow{2}{*}{ Species } & \multicolumn{3}{c}{ Seed moisture content at harvest } \\
\cline { 2 - 4 } & $45 \%$ & $35 \%$ & $25 \%$ \\
\hline Festuca arundinacea & $1.92 \mathrm{a}$ & $1.99 \mathrm{a}$ & $2.03 \mathrm{a}$ \\
Festuca rubra & $1.13 \mathrm{a}$ & $1.15 \mathrm{a}$ & $1.18 \mathrm{a}$ \\
Dactylis glomerata & $1.15 \mathrm{a}$ & $1.19 \mathrm{a}$ & $1.22 \mathrm{a}$ \\
\hline
\end{tabular}

Note. Mean values in a row followed by the same letter are not significantly different (LSD test, $p>0.05$ ).

A post-harvest maturation period, seed moisture content, drying temperatures and their interactions significantly affected seed germination and dormancy, while the effects of seed lot, year and their interactions were not significant (Table 2). Hence, in what follows, we present results on seed germination and dormancy as an average of three lots and two years.

Germination and dormancy of seeds harvested with the different moisture contents and immediately after drying at various temperatures are presented in Table 3. The lowest germination and the highest dormancy were determined in seeds of tall fescue and red fescue harvested with the moisture content of $45 \%$, while the corresponding values in cocksfoot were recorded in seeds harvested with the moisture content of $25 \%$. In all three species, regardless of the moisture content at harvest, the lowest germination was recorded after conventional drying $\left(22^{\circ} \mathrm{C}\right)$, which was a result of high seed dormancy. Generally, the higher drying temperatures were $\left(60^{\circ} \mathrm{C}\right.$ and $\left.70^{\circ} \mathrm{C}\right)$ the lower seed dormancy and germination were. The highest seed germination immediately after drying was recorded in tall fescue seeds harvested with the moisture content of $45 \%$ and dried at a temperature of $60^{\circ} \mathrm{C}$ and seeds harvested with the moisture content of $35 \%$ and $25 \%$ and dried at 
Table 2. Statistical probabilities of $F$-test for germination and dormancy (\%)

\begin{tabular}{cccccccc}
\hline \multirow{2}{*}{ Source } & d.f. & \multicolumn{2}{c}{ Festuca arundinacea } & \multicolumn{2}{c}{ Festuca rubra } & \multicolumn{2}{c}{ Dactylis glomerata } \\
\cline { 3 - 8 } & germination & dormancy & germination & dormancy & germination & dormancy \\
\hline Seed maturation (SM) & 3 & $* *$ & $* *$ & $* *$ & $* *$ & $* *$ & $* *$ \\
Lots (L) & 2 & $\mathrm{~ns}$ & $\mathrm{~ns}$ & $\mathrm{~ns}$ & $\mathrm{~ns}$ & $\mathrm{~ns}$ & $\mathrm{~ns}$ \\
Seed moisture (M) & 2 & $* *$ & $* *$ & $* *$ & $* *$ & $* *$ & $* *$ \\
Drying temperature (T) & 5 & $* *$ & $* *$ & $* *$ & $* *$ & $* *$ & $* *$ \\
Year (Y) & 1 & $\mathrm{~ns}$ & $\mathrm{~ns}$ & $\mathrm{~ns}$ & $\mathrm{~ns}$ & $\mathrm{~ns}$ & $\mathrm{~ns}$ \\
$\mathrm{SM} \times \mathrm{L}$ & 6 & $\mathrm{~ns}$ & $\mathrm{~ns}$ & $\mathrm{~ns}$ & $\mathrm{~ns}$ & $\mathrm{~ns}$ & $\mathrm{~ns}$ \\
$\mathrm{SM} \times \mathrm{M}$ & 6 & $* *$ & $* *$ & $* *$ & $* *$ & $* *$ & $* *$ \\
$\mathrm{~L} \times \mathrm{M}$ & 4 & $\mathrm{~ns}$ & $\mathrm{~ns}$ & $\mathrm{~ns}$ & $\mathrm{~ns}$ & $\mathrm{~ns}$ & $\mathrm{~ns}$ \\
$\mathrm{SM} \times \mathrm{T}$ & 15 & $* *$ & $* *$ & $* *$ & $* *$ & $* *$ & $* *$ \\
$\mathrm{~L} \times \mathrm{T}$ & 10 & $\mathrm{~ns}$ & $\mathrm{~ns}$ & $\mathrm{~ns}$ & $\mathrm{~ns}$ & $\mathrm{~ns}$ & $\mathrm{~ns}$ \\
$\mathrm{M} \times \mathrm{T}$ & 10 & $* *$ & $* *$ & $* *$ & $* *$ & $* *$ & $* *$ \\
$\mathrm{SM} \times \mathrm{L} \times \mathrm{M}$ & 12 & $\mathrm{~ns}$ & $\mathrm{~ns}$ & $\mathrm{~ns}$ & $\mathrm{~ns}$ & $\mathrm{~ns}$ & $\mathrm{~ns}$ \\
$\mathrm{SM} \times \mathrm{L} \times \mathrm{T}$ & 30 & $\mathrm{~ns}$ & $\mathrm{~ns}$ & $\mathrm{~ns}$ & $\mathrm{~ns}$ & $\mathrm{~ns}$ & $\mathrm{~ns}$ \\
$\mathrm{SM} \times \mathrm{M} \times \mathrm{T}$ & 30 & $*$ & $*$ & $*$ & $*$ & $*$ & $*$ \\
$\mathrm{~L} \times \mathrm{M} \times \mathrm{T}$ & 20 & $\mathrm{~ns}$ & $\mathrm{~ns}$ & $\mathrm{~ns}$ & $\mathrm{~ns}$ & $\mathrm{~ns}$ & $\mathrm{~ns}$ \\
$\mathrm{SM} \times \mathrm{L} \times \mathrm{M} \times \mathrm{T}$ & 60 & $\mathrm{~ns}$ & $\mathrm{~ns}$ & $\mathrm{~ns}$ & $\mathrm{~ns}$ & $\mathrm{~ns}$ & $\mathrm{~ns}$ \\
$\mathrm{Y} \times \mathrm{SM}$ & 3 & $\mathrm{~ns}$ & $\mathrm{~ns}$ & $\mathrm{~ns}$ & $\mathrm{~ns}$ & $\mathrm{~ns}$ & $\mathrm{~ns}$ \\
$\mathrm{Y} \times \mathrm{L}$ & 2 & $\mathrm{~ns}$ & $\mathrm{~ns}$ & $\mathrm{~ns}$ & $\mathrm{~ns}$ & $\mathrm{~ns}$ & $\mathrm{~ns}$ \\
$\mathrm{Y} \times \mathrm{M}$ & 2 & $\mathrm{~ns}$ & $\mathrm{~ns}$ & $\mathrm{~ns}$ & $\mathrm{~ns}$ & $\mathrm{~ns}$ & $\mathrm{~ns}$ \\
$\mathrm{Y} \times \mathrm{T}$ & 5 & $\mathrm{~ns}$ & $\mathrm{~ns}$ & $\mathrm{~ns}$ & $\mathrm{~ns}$ & $\mathrm{~ns}$ & $\mathrm{~ns}$ \\
$\mathrm{Y} \times \mathrm{SM} \times \mathrm{L} \times \mathrm{M} \times \mathrm{T}$ & 60 & $\mathrm{~ns}$ & $\mathrm{~ns}$ & $\mathrm{~ns}$ & $\mathrm{~ns}$ & $\mathrm{~ns}$ & $\mathrm{~ns}$ \\
\hline
\end{tabular}

d.f. - degrees of freedom; ${ }^{*}-p<0.05, * *-p<0.01$, ns - not significant

Table 3. Germination and dormancy (\%) of seed immediately after drying

\begin{tabular}{|c|c|c|c|c|c|c|c|}
\hline \multirow{2}{*}{$\begin{array}{c}\text { Seed } \\
\text { moisture }\end{array}$} & \multirow{2}{*}{$\begin{array}{c}\text { Drying } \\
\text { temperature } \\
{ }^{\circ} \mathrm{C}\end{array}$} & \multicolumn{2}{|c|}{ Festuca arundinacea } & \multicolumn{2}{|c|}{ Festuca rubra } & \multicolumn{2}{|c|}{ Dactylis glomerata } \\
\hline & & germination & dormancy & germination & dormancy & germination & dormancy \\
\hline \multirow{6}{*}{$45 \%$} & 70 & $75 \mathrm{~d}$ & $2 \mathrm{f}$ & $66 \mathrm{~d}$ & $0 \mathrm{f}$ & $65 \mathrm{~d}$ & Of \\
\hline & 60 & $83 \mathrm{a}$ & $5 \mathrm{e}$ & $69 \mathrm{c}$ & $2 \mathrm{e}$ & $72 \mathrm{c}$ & $3 e$ \\
\hline & 50 & $80 \mathrm{~b}$ & $10 \mathrm{~d}$ & $86 \mathrm{a}$ & $7 \mathrm{~d}$ & $80 \mathrm{~b}$ & $7 d$ \\
\hline & 40 & $77 \mathrm{c}$ & $21 \mathrm{c}$ & $87 \mathrm{a}$ & $10 \mathrm{c}$ & $85 \mathrm{a}$ & $11 \mathrm{c}$ \\
\hline & 30 & $75 \mathrm{~d}$ & $25 \mathrm{~b}$ & $78 \mathrm{~b}$ & $20 \mathrm{~b}$ & $72 \mathrm{c}$ & $19 \mathrm{~b}$ \\
\hline & 22 & $67 \mathrm{e}$ & $31 \mathrm{a}$ & $66 \mathrm{~d}$ & $28 \mathrm{a}$ & $63 \mathrm{e}$ & $32 \mathrm{a}$ \\
\hline \multicolumn{2}{|c|}{ Mean } & 76 & 16 & 75 & 11 & 73 & 12 \\
\hline \multirow{6}{*}{$35 \%$} & 70 & $75 \mathrm{c}$ & $2 \mathrm{e}$ & $67 \mathrm{c}$ & $0 \mathrm{f}$ & $66 \mathrm{c}$ & $0 \mathrm{f}$ \\
\hline & 60 & $88 \mathrm{~b}$ & $7 \mathrm{~d}$ & $70 \mathrm{~b}$ & $4 \mathrm{e}$ & $75 \mathrm{~b}$ & $5 \mathrm{e}$ \\
\hline & 50 & $92 \mathrm{a}$ & $7 \mathrm{~d}$ & $80 \mathrm{a}$ & $14 \mathrm{~d}$ & $88 \mathrm{a}$ & $8 \mathrm{~d}$ \\
\hline & 40 & $91 \mathrm{a}$ & $8 \mathrm{c}$ & $82 \mathrm{a}$ & $16 \mathrm{c}$ & $89 \mathrm{a}$ & $10 \mathrm{c}$ \\
\hline & 30 & $88 \mathrm{~b}$ & $10 \mathrm{~b}$ & $80 \mathrm{a}$ & $19 \mathrm{~b}$ & $77 \mathrm{~b}$ & $19 \mathrm{~b}$ \\
\hline & 22 & $66 \mathrm{~d}$ & $30 \mathrm{a}$ & $66 \mathrm{c}$ & $29 \mathrm{a}$ & $61 \mathrm{~d}$ & $29 \mathrm{a}$ \\
\hline \multicolumn{2}{|c|}{ Mean } & 83 & 11 & 74 & 14 & 76 & 12 \\
\hline \multirow{6}{*}{$25 \%$} & 70 & $76 \mathrm{c}$ & $4 d$ & $6 \mathrm{e}$ & $0 \mathrm{f}$ & $71 \mathrm{~b}$ & $0 \mathrm{f}$ \\
\hline & 60 & $88 \mathrm{~b}$ & $7 \mathrm{~d}$ & $72 \mathrm{~d}$ & $6 \mathrm{e}$ & $78 \mathrm{a}$ & $5 \mathrm{e}$ \\
\hline & 50 & $90 \mathrm{a}$ & $9 \mathrm{c}$ & $79 \mathrm{~b}$ & $15 \mathrm{~d}$ & $79 \mathrm{a}$ & $12 \mathrm{~d}$ \\
\hline & 40 & $90 \mathrm{a}$ & $9 \mathrm{c}$ & $81 \mathrm{a}$ & $18 \mathrm{c}$ & $69 \mathrm{c}$ & $22 \mathrm{c}$ \\
\hline & 30 & $87 \mathrm{~b}$ & $11 \mathrm{~b}$ & $77 \mathrm{c}$ & $20 \mathrm{~b}$ & $62 \mathrm{~d}$ & $31 b$ \\
\hline & 22 & $65 \mathrm{~d}$ & $32 \mathrm{a}$ & $65 \mathrm{f}$ & $30 \mathrm{a}$ & $61 \mathrm{~d}$ & $33 \mathrm{a}$ \\
\hline \multicolumn{2}{|c|}{ Mean } & 83 & 12 & 63 & 15 & 70 & 17 \\
\hline
\end{tabular}

Note. Different letters within species and treatment combinations indicate significant differences (LSD test, $p<0.01$ ).

the temperatures ranging from $40^{\circ} \mathrm{C}$ to $50^{\circ} \mathrm{C}$. The highest germination of red fescue seeds was recorded immediately after drying at the temperatures ranging from $40^{\circ} \mathrm{C}$ to $50^{\circ} \mathrm{C}$, regardless of the moisture content. Moreover, the highest germination of cocksfoot seeds harvested with the moisture content of $45 \%$ and $35 \%$ was recorded after drying at the temperatures ranging from $40^{\circ} \mathrm{C}$ to $50^{\circ} \mathrm{C}$, while the highest germination of seeds harvested with the moisture content of $25 \%$ was recorded after drying at the temperatures ranging from $50^{\circ} \mathrm{C}$ to $60^{\circ} \mathrm{C}$. The absolutely highest germination of tall fescue was recorded for seeds harvested with the moisture content of $35 \%$ and dried at 
the temperature of $50^{\circ} \mathrm{C}(92 \%)$, while the corresponding values in red fescue and cocksfoot were recorded in seeds with the moisture content of $45 \%$ and $35 \%$ and drying temperatures of $50^{\circ} \mathrm{C}(87 \%)$ and $40^{\circ} \mathrm{C}(89 \%)$, respectively.

Germination and dormancy of seeds, harvested with different moisture contents, recorded three months after drying at various temperatures are presented in Table 4. Averaged over all three species, germination was the lowest in seeds harvested with the moisture content of $45 \%$. Regardless of the moisture content at harvest, the lowest germination three months after drying was recorded in seeds dried at $70^{\circ} \mathrm{C}$, while the highest germination was recorded in seeds dried at the temperature varying from $40^{\circ} \mathrm{C}$ to $50^{\circ} \mathrm{C}$, except for cocksfoot seeds harvested with the moisture content of $25 \%$ in which the highest germination was detected in seeds dried at the temperature varying from $50^{\circ} \mathrm{C}$ to $60^{\circ} \mathrm{C}$. The absolutely highest germination of tall fescue three months after drying was recorded in seeds harvested with the moisture content of $25 \%$ and dried at the temperature of $50^{\circ} \mathrm{C}(94 \%)$, while the corresponding values in red fescue and cocksfoot were recorded in seeds harvested with the moisture content of $45 \%$ and $35 \%$ and dried at temperatures of $50^{\circ} \mathrm{C}(82 \%)$ and $50^{\circ} \mathrm{C}$ (91\%), respectively. Averaged over all temperatures, germination and dormancy after harvest of seeds with the moisture content of $35 \%$ and $25 \%$ in all three species were slightly higher and lower, respectively, compared to values obtained immediately after drying.

Table 4. Germination and dormancy (\%) of seeds three months after drying

\begin{tabular}{|c|c|c|c|c|c|c|c|}
\hline \multirow{2}{*}{$\begin{array}{c}\text { Seed } \\
\text { moisture }\end{array}$} & \multirow{2}{*}{$\begin{array}{c}\text { Drying } \\
\text { temperature } \\
{ }^{\circ} \mathrm{C}\end{array}$} & \multicolumn{2}{|c|}{ Festuca arundinacea } & \multicolumn{2}{|c|}{ Festuca rubra } & \multicolumn{2}{|c|}{ Dactylis glomerata } \\
\hline & & germination & dormancy & germination & dormancy & germination & dormancy \\
\hline \multirow{6}{*}{$45 \%$} & 70 & $70 \mathrm{c}$ & $0 \mathrm{e}$ & $62 \mathrm{~d}$ & $0 \mathrm{e}$ & $64 \mathrm{e}$ & $0 \mathrm{f}$ \\
\hline & 60 & $75 \mathrm{~b}$ & $0 \mathrm{e}$ & $76 \mathrm{~b}$ & $0 \mathrm{e}$ & $73 \mathrm{c}$ & $2 \mathrm{e}$ \\
\hline & 50 & $80 \mathrm{a}$ & $3 \mathrm{~d}$ & $80 \mathrm{a}$ & $3 \mathrm{~d}$ & $84 \mathrm{a}$ & $4 \mathrm{~d}$ \\
\hline & 40 & $79 a$ & $5 \mathrm{c}$ & $79 a$ & $5 \mathrm{c}$ & $83 \mathrm{a}$ & $8 \mathrm{c}$ \\
\hline & 30 & $75 \mathrm{~b}$ & $12 \mathrm{~b}$ & $79 \mathrm{a}$ & $11 \mathrm{~b}$ & $80 \mathrm{~b}$ & $12 \mathrm{~b}$ \\
\hline & 22 & $71 \mathrm{c}$ & $19 \mathrm{a}$ & $65 \mathrm{c}$ & $18 \mathrm{a}$ & $67 \mathrm{~d}$ & $21 \mathrm{a}$ \\
\hline \multicolumn{2}{|c|}{ Mean } & 75 & 7 & 74 & 6 & 75 & 8 \\
\hline \multirow{6}{*}{$35 \%$} & 70 & $74 d$ & $0 \mathrm{f}$ & $65 d$ & $0 \mathrm{e}$ & $63 \mathrm{~d}$ & $0 \mathrm{e}$ \\
\hline & 60 & 88 bc & $2 \mathrm{e}$ & $78 \mathrm{dc}$ & $2 \mathrm{~d}$ & $79 b$ & $2 \mathrm{~d}$ \\
\hline & 50 & $92 \mathrm{a}$ & $4 d$ & $82 \mathrm{a}$ & $6 \mathrm{c}$ & $91 \mathrm{a}$ & $8 \mathrm{c}$ \\
\hline & 40 & 93 a & $6 \mathrm{c}$ & $80 \mathrm{~b}$ & $6 \mathrm{c}$ & $90 \mathrm{a}$ & $8 \mathrm{c}$ \\
\hline & 30 & $89 \mathrm{~b}$ & $9 \mathrm{~b}$ & $79 \mathrm{~b}$ & $9 \mathrm{~b}$ & $79 \mathrm{~b}$ & $18 \mathrm{~b}$ \\
\hline & 22 & $78 \mathrm{c}$ & $19 \mathrm{a}$ & $76 \mathrm{c}$ & $22 \mathrm{a}$ & $65 \mathrm{c}$ & $26 \mathrm{a}$ \\
\hline \multicolumn{2}{|c|}{ Mean } & 86 & 7 & 77 & 8 & 78 & 10 \\
\hline \multirow{6}{*}{$25 \%$} & 70 & $75 d$ & $0 \mathrm{f}$ & $65 \mathrm{c}$ & $0 \mathrm{f}$ & $70 \mathrm{c}$ & $0 \mathrm{f}$ \\
\hline & 60 & $89 \mathrm{~b}$ & $2 \mathrm{e}$ & $79 a$ & $3 \mathrm{e}$ & 89 a & $6 \mathrm{e}$ \\
\hline & 50 & $94 \mathrm{a}$ & $4 \mathrm{~d}$ & $80 \mathrm{a}$ & $5 \mathrm{~d}$ & $90 \mathrm{a}$ & $8 \mathrm{~d}$ \\
\hline & 40 & 93 a & $6 \mathrm{c}$ & $80 \mathrm{a}$ & $10 \mathrm{c}$ & $81 \mathrm{~b}$ & $14 \mathrm{c}$ \\
\hline & 30 & $90 \mathrm{~b}$ & $9 \mathrm{~b}$ & $79 a$ & $18 \mathrm{~b}$ & $80 \mathrm{~b}$ & $18 \mathrm{~b}$ \\
\hline & 22 & $79 \mathrm{c}$ & $20 \mathrm{a}$ & $76 \mathrm{~b}$ & $23 \mathrm{a}$ & $69 \mathrm{c}$ & $28 \mathrm{a}$ \\
\hline \multicolumn{2}{|r|}{ Mean } & 87 & 7 & 77 & 10 & 80 & 12 \\
\hline
\end{tabular}

Explanation under Table 3

Germination and dormancy of seeds, harvested with different moisture contents, recorded eight months after drying at various temperatures are presented in Table 5. Averaged over all drying temperatures, germination was the lowest in seeds with the moisture content of $45 \%$, while the highest germination was in seeds harvested with $25 \%$ moisture content. Regardless of the moisture content at harvest, the temperatures varying between $30^{\circ} \mathrm{C}$ and $50^{\circ} \mathrm{C}$ were the most optimal in the majority of cases in all three species. Seed germination recorded eight months after drying at higher $\left(60-70^{\circ} \mathrm{C}\right)$ temperatures tended to decrease in comparison with germination measured after three months or immediately after harvest, especially when combined with high moisture content $(45 \%)$ in the harvested seed. The absolutely highest germination of tall fescue eight months after drying was recorded in seeds harvested with the moisture content of $25 \%$ and dried at the temperature of $40^{\circ} \mathrm{C}(96 \%)$, while the corresponding values in red fescue and cocksfoot were recorded in seeds harvested with the moisture contents of $25 \%$ and $35 \%$ and drying temperatures of $30^{\circ} \mathrm{C}(95 \%)$ and $40^{\circ} \mathrm{C}$ $(92 \%)$, respectively. The greatest percentage of dormant seeds during this period was recorded after floor drying of seeds harvested with the moisture content of $25 \%$ and it amounted to $8 \%, 9 \%$ and even to $20 \%$ in tall fescue, red fescue and cocksfoot, respectively.

Germination and dormancy of seeds, harvested with different moisture contents, recorded fourteen months after drying at various temperatures are presented in Table 6. Germination was the lowest in seeds harvested with the moisture content of $45 \%$, while the highest germination was in seeds harvested with $25 \%$ moisture content. In the majority of cases, floor drying $\left(22^{\circ} \mathrm{C}\right)$ and drying at $30^{\circ} \mathrm{C}$ were the most optimal for all three species regardless of the moisture content at harvest. Seed germination recorded after drying at higher $\left(60-70^{\circ} \mathrm{C}\right)$ temperatures tended to decrease in comparison with initial germination measured immediately after harvest. 
Table 5. Germination and dormancy (\%) of seeds eight months after drying

\begin{tabular}{|c|c|c|c|c|c|c|c|}
\hline \multirow{2}{*}{$\begin{array}{c}\text { Seed } \\
\text { moisture }\end{array}$} & \multirow{2}{*}{$\begin{array}{c}\text { Drying } \\
\text { temperature } \\
{ }^{\circ} \mathrm{C}\end{array}$} & \multicolumn{2}{|c|}{ Festuca arundinacea } & \multicolumn{2}{|c|}{ Festuca rubra } & \multicolumn{2}{|c|}{ Dactylis glomerata } \\
\hline & & germination & dormancy & germination & dormancy & germination & dormancy \\
\hline \multirow{6}{*}{$45 \%$} & 70 & $68 \mathrm{c}$ & $0 \mathrm{c}$ & $60 \mathrm{c}$ & $0 \mathrm{c}$ & $67 \mathrm{c}$ & $0 \mathrm{~d}$ \\
\hline & 60 & $77 \mathrm{~b}$ & $0 \mathrm{c}$ & $73 \mathrm{~b}$ & $0 \mathrm{c}$ & $71 \mathrm{~b}$ & $0 \mathrm{~d}$ \\
\hline & 50 & $79 \mathrm{~b}$ & $0 \mathrm{c}$ & $74 \mathrm{~b}$ & $0 \mathrm{c}$ & $81 \mathrm{a}$ & $1 \mathrm{~d}$ \\
\hline & 40 & $82 \mathrm{a}$ & $2 \mathrm{~b}$ & $81 \mathrm{a}$ & $0 \mathrm{c}$ & $82 \mathrm{a}$ & $5 \mathrm{c}$ \\
\hline & 30 & $84 \mathrm{a}$ & $3 \mathrm{~b}$ & $82 \mathrm{a}$ & $2 \mathrm{~b}$ & $81 \mathrm{a}$ & $8 \mathrm{~b}$ \\
\hline & 22 & $85 \mathrm{a}$ & $6 \mathrm{a}$ & $72 b$ & $5 \mathrm{a}$ & $70 \mathrm{~b}$ & $12 \mathrm{a}$ \\
\hline \multicolumn{2}{|c|}{ Mean } & 79 & 2 & 74 & 1 & 75 & 4 \\
\hline \multirow{6}{*}{$35 \%$} & 70 & $74 \mathrm{c}$ & $0 \mathrm{~d}$ & $67 \mathrm{~d}$ & $0 \mathrm{~d}$ & $70 \mathrm{e}$ & $0 \mathrm{e}$ \\
\hline & 60 & $90 \mathrm{~b}$ & $0 \mathrm{~d}$ & $84 \mathrm{~b}$ & $0 \mathrm{~d}$ & $81 \mathrm{c}$ & $2 d$ \\
\hline & 50 & $94 \mathrm{a}$ & $2 \mathrm{~cd}$ & 89 a & $4 \mathrm{c}$ & $89 \mathrm{~b}$ & $3 \mathrm{~cd}$ \\
\hline & 40 & $93 \mathrm{a}$ & $3 \mathrm{c}$ & $90 \mathrm{a}$ & $4 \mathrm{c}$ & $92 \mathrm{a}$ & $4 \mathrm{c}$ \\
\hline & 30 & $90 \mathrm{~b}$ & $7 \mathrm{~b}$ & $89 \mathrm{a}$ & $7 \mathrm{~b}$ & $80 \mathrm{c}$ & $12 \mathrm{~b}$ \\
\hline & 22 & $89 \mathrm{~b}$ & $9 \mathrm{a}$ & $78 \mathrm{c}$ & $12 \mathrm{a}$ & $74 \mathrm{~d}$ & $14 \mathrm{a}$ \\
\hline \multicolumn{2}{|c|}{ Mean } & 88 & 4 & 83 & 5 & 81 & 6 \\
\hline \multirow{6}{*}{$25 \%$} & 70 & $74 \mathrm{c}$ & $0 \mathrm{~d}$ & $69 \mathrm{~d}$ & $0 \mathrm{c}$ & $72 \mathrm{e}$ & $0 \mathrm{e}$ \\
\hline & 60 & $92 \mathrm{~b}$ & $0 \mathrm{~d}$ & $85 \mathrm{~b}$ & $0 \mathrm{c}$ & $82 \mathrm{c}$ & $2 \mathrm{~d}$ \\
\hline & 50 & $95 \mathrm{a}$ & $2 \mathrm{~cd}$ & $92 \mathrm{a}$ & $1 \mathrm{c}$ & $90 \mathrm{a}$ & $6 \mathrm{~d}$ \\
\hline & 40 & $96 \mathrm{a}$ & $3 c$ & $94 \mathrm{a}$ & $4 \mathrm{~b}$ & $89 a$ & $10 \mathrm{c}$ \\
\hline & 30 & $91 \mathrm{~b}$ & $6 \mathrm{~b}$ & $95 \mathrm{a}$ & $4 \mathrm{~b}$ & $86 \mathrm{~b}$ & $12 \mathrm{~b}$ \\
\hline & 22 & $90 \mathrm{~b}$ & $8 \mathrm{a}$ & $80 \mathrm{c}$ & $9 \mathrm{a}$ & $77 \mathrm{~d}$ & $20 \mathrm{a}$ \\
\hline \multicolumn{2}{|c|}{ Mean } & 90 & 3 & 86 & 3 & 83 & 8 \\
\hline
\end{tabular}

Explanation under Table 3

Table 6. Germination and dormancy (\%) of seeds fourteen months after drying

\begin{tabular}{|c|c|c|c|c|c|c|c|}
\hline \multirow{2}{*}{$\begin{array}{c}\text { Seed } \\
\text { moisture }\end{array}$} & \multirow{2}{*}{$\begin{array}{c}\text { Drying } \\
\text { temperature } \\
{ }^{\circ} \mathrm{C}\end{array}$} & \multicolumn{2}{|c|}{ Festuca arundinacea } & \multicolumn{2}{|c|}{ Festuca rubra } & \multicolumn{2}{|c|}{ Dactylis glomerata } \\
\hline & & germination & dormancy & germination & dormancy & germination & dormancy \\
\hline \multirow{6}{*}{$45 \%$} & 70 & $63 \mathrm{e}$ & $0 \mathrm{a}$ & $55 \mathrm{e}$ & $0 \mathrm{a}$ & $66 \mathrm{e}$ & $0 \mathrm{a}$ \\
\hline & 60 & $65 \mathrm{~d}$ & $0 \mathrm{a}$ & $59 \mathrm{~d}$ & $0 \mathrm{a}$ & $70 \mathrm{~d}$ & $0 \mathrm{a}$ \\
\hline & 50 & $70 \mathrm{c}$ & $0 \mathrm{a}$ & $62 \mathrm{c}$ & $0 \mathrm{a}$ & $82 \mathrm{c}$ & $0 \mathrm{a}$ \\
\hline & 40 & $77 \mathrm{~b}$ & $0 \mathrm{a}$ & $69 \mathrm{~b}$ & $0 \mathrm{a}$ & $85 \mathrm{~b}$ & $0 \mathrm{a}$ \\
\hline & 30 & $80 \mathrm{a}$ & $0 \mathrm{a}$ & $72 \mathrm{a}$ & $0 \mathrm{a}$ & $89 \mathrm{a}$ & $0 \mathrm{a}$ \\
\hline & 22 & $81 \mathrm{a}$ & $0 \mathrm{a}$ & $72 \mathrm{a}$ & $0 \mathrm{a}$ & $88 \mathrm{a}$ & $0 \mathrm{a}$ \\
\hline \multicolumn{2}{|c|}{ Mean } & 73 & 0 & 65 & 0 & 80 & 0 \\
\hline \multirow{6}{*}{$35 \%$} & 70 & $70 \mathrm{~d}$ & $0 \mathrm{a}$ & $60 \mathrm{~d}$ & $0 \mathrm{a}$ & $69 \mathrm{~d}$ & $0 \mathrm{~b}$ \\
\hline & 60 & $75 \mathrm{c}$ & $0 \mathrm{a}$ & $66 \mathrm{c}$ & $0 \mathrm{a}$ & $80 \mathrm{c}$ & $0 \mathrm{~b}$ \\
\hline & 50 & $75 \mathrm{c}$ & $0 \mathrm{a}$ & $69 \mathrm{~b}$ & $0 \mathrm{a}$ & $90 \mathrm{~b}$ & $0 \mathrm{~b}$ \\
\hline & 40 & $78 \mathrm{~b}$ & $0 \mathrm{a}$ & $72 \mathrm{a}$ & $0 \mathrm{a}$ & $91 \mathrm{ab}$ & $0 \mathrm{~b}$ \\
\hline & 30 & $82 \mathrm{a}$ & $0 \mathrm{a}$ & $73 \mathrm{a}$ & $0 \mathrm{a}$ & $93 \mathrm{a}$ & $1 \mathrm{ab}$ \\
\hline & 22 & $82 \mathrm{a}$ & $0 \mathrm{a}$ & $73 \mathrm{a}$ & $0 \mathrm{a}$ & $93 \mathrm{a}$ & $2 \mathrm{a}$ \\
\hline \multicolumn{2}{|c|}{ Mean } & 77 & 0 & 69 & 0 & 86 & 0 \\
\hline \multirow{6}{*}{$25 \%$} & 70 & $71 \mathrm{e}$ & $0 \mathrm{~b}$ & $61 \mathrm{f}$ & $0 \mathrm{~b}$ & $71 \mathrm{~d}$ & $0 \mathrm{~b}$ \\
\hline & 60 & $77 \mathrm{~d}$ & $0 \mathrm{~b}$ & $68 \mathrm{e}$ & $0 \mathrm{~b}$ & $81 \mathrm{c}$ & $0 \mathrm{~b}$ \\
\hline & 50 & $82 \mathrm{c}$ & $0 \mathrm{~b}$ & $70 \mathrm{~d}$ & $0 \mathrm{~b}$ & $92 \mathrm{~b}$ & $0 \mathrm{~b}$ \\
\hline & 40 & $88 \mathrm{~b}$ & $0 \mathrm{~b}$ & $72 \mathrm{c}$ & $0 \mathrm{~b}$ & $94 \mathrm{a}$ & $1 \mathrm{ab}$ \\
\hline & 30 & $90 \mathrm{ab}$ & $0 \mathrm{~b}$ & $75 \mathrm{~b}$ & $0 \mathrm{~b}$ & $95 \mathrm{a}$ & $1 \mathrm{ab}$ \\
\hline & 22 & $92 \mathrm{a}$ & $2 \mathrm{a}$ & $78 \mathrm{a}$ & $1 \mathrm{a}$ & $94 \mathrm{a}$ & $3 \mathrm{a}$ \\
\hline \multicolumn{2}{|c|}{ Mean } & 83 & 0 & 71 & 0 & 88 & 1 \\
\hline
\end{tabular}

Explanation under Table 3

In the period between eighteenth and fourteenth month after drying, seeds harvested with the moisture content of $45 \%$ were losing germination more quickly than those harvested with the moisture content of $25 \%$, and this difference, on the average for all temperatures, amounted to 10,14 and $8 \%$ in tall fescue, red fescue and cocksfoot, respectively. The absolutely highest germination of tall fescue and red fescue fourteen months after drying was recorded in seeds harvested with the moisture content of $25 \%$ and dried at the temperature of $22^{\circ} \mathrm{C}(92 \%$ and 
$78 \%$, respectively), while the corresponding values in cocksfoot were recorded in seeds harvested with the moisture contents of $25 \%$ and dried at the temperature of $30^{\circ} \mathrm{C}(95 \%)$. Fourteen months after drying there were no dormant seeds in samples of the species belonging to the genus Festuca harvested with the moisture contents of $45 \%$ and $35 \%$, while there were still dormant seeds in cocksfoot samples harvested with the moisture content of $35 \%$ and dried at temperatures of $22^{\circ} \mathrm{C}$ and $30^{\circ} \mathrm{C}$. A total of $1-3 \%$ of seeds harvested with the moisture content of $25 \%$ and conventionally dried $\left(22^{\circ} \mathrm{C}\right)$ were dormant.

The coefficients of correlation $(r)$ between seed germination and seedling traits are presented in Table 7. Seed germination in tall fescue and cocksfoot was significantly correlated with shoot and root lengths, as well as seedling biomass. However, in red fescue only seedling biomass was significantly related to germination $(p<0.05)$.

Table 7. Coefficients of correlation ( $r)$ between germination and seedling traits

\begin{tabular}{lccc}
\hline \multirow{2}{*}{ Species } & \multicolumn{3}{c}{ Seedling trait } \\
\cline { 2 - 4 } & $\begin{array}{c}\text { shoot } \\
\mathrm{cm}\end{array}$ & $\begin{array}{c}\text { root } \\
\mathrm{cm}\end{array}$ & $\begin{array}{c}\text { biomass } \\
\mathrm{mg}\end{array}$ \\
\hline Festuca arundinacea & $0.389^{* * *}$ & $0.395^{* * *}$ & $0.305^{* *}$ \\
Festuca rubra & $0.245^{*}$ & $0.235^{*}$ & $0.288^{*}$ \\
Dactylis glomerata & $0.299^{* *}$ & $0.326^{* *}$ & $0.313^{* *}$ \\
\hline$*-p<0.05, * *-p<0.05, * * *-p<0.001$ &
\end{tabular}

\section{Discussion}

Seeds harvested with $25 \%$ moisture content had higher 1000-kernel weight in all three species compared to seeds harvested with $45 \%$ moisture content, but this increase was not statistically significant. lepetys (2001) has also recorded the increase of 1000-kernel weight in several fodder grasses in seeds harvested with the moisture content of $25 \%$ in relation to seeds harvested with the moisture content of $45 \%$. Lots did not significantly affect varying of seed germination and dormancy as it was expected considering that regions of central, eastern and south-eastern Serbia are geographically small, do not differ much in climatic and edaphic conditions, and the applied growing practices were also similar. Although several previous studies of various species showed that differences among consecutive years were larger than differences among test sites within a region of south-east Europe (Rizza et al., 2004; Sudarić et al., 2006; Dodig et al., 2008), the year in the present study did not have a significant effect on the variation of seed germination and dormancy of the three observed species of fodder crops.

Dormancy is a physiological state enabling the plants to survive for a long time without germinating (if the conditions are not favourable for the germination to be completed). The dormancy mechanisms can be divided into those based in the tissues that surround the embryo and those found within the embryo or endosperm (Adkins et al., 2002). In our study, immediately after seed harvest the level of dormancy after conventional drying and drying at $30^{\circ} \mathrm{C}$ was high, which caused low germination. On the other hand, drying at $70^{\circ} \mathrm{C}$ reduced dormancy, but also reduced germination, and considering all moisture contents of harvested seeds, germination was high and amounted to 75-76, 65-67 and 65-71\% in tall fescue, red fescue and cocksfoot, respectively. High $\left(70-80^{\circ} \mathrm{C}\right)$ drying temperatures stressfully affect seeds of tall fescue, meadow fescue and red fescue, which leads to irreversible germination loss during seed storage (Stanisavljević et al., 2012). High (above $70^{\circ} \mathrm{C}$ ) temperature treatments are used in some fodder grasses such as bread grass (Brachiaria brizantha (A. Rich) Stapf) to increase germination (Martins, Silva, 2001). The seed dormancy level immediately after harvest, for instance in tall fescue, depends on temperatures during maturing, whereby the temperature increase leads to the dormancy decrease (Boyce et al., 1976).

Three months after harvest (September-October) is the optimal autumn sowing period for fodder grasses in the region of south-eastern Europe. In this period, a slight decline in germination of all three species in relation to the period immediately after drying occurred after drying at the temperature of $70^{\circ} \mathrm{C}$. The negative interaction between the temperature and seed moisture was mostly pronounced in seeds dried at $60^{\circ} \mathrm{C}$, whereby germination of seeds harvested with the moisture content of $45 \%$ was lower by $3 \%$ and $16 \%$ (red fescue and cocksfoot, respectively) in relation to seeds harvested with the moisture content of $25 \%$. The significant effect of the combination of seed moisture and drying temperature on seed germination was established in Kentucky bluegrass (Poa pratensis L.) (Sveinsson, Björnsson, 1994). According to Probert (2000), the temperature, together with the moisture content, determines the rate of deterioration in dry and moist seeds. Seeds harvested with the moisture content of $45 \%$ generally had lower maximum germination, but this moisture content in combination with the optimal $\left(40-50^{\circ} \mathrm{C}\right)$ drying temperature results in satisfactory germination (80-84\%). However, the most suitable seed for this sowing period is tall fescue seed harvested with the moisture content of $25 \%$ and dried at $50^{\circ} \mathrm{C}$ (germination 94\%) and red fescue and cocksfoot seeds harvested with the moisture content of $35 \%$ and dried at $50^{\circ} \mathrm{C}(82 \%$ and $91 \%$, respectively).

The spring sowing period of fodder grasses in the region of south-eastern Europe begins eight months after harvest (March-April) when there are sufficient precipitation for a successful establishment of meadows and pastures. This is also the period of the greatest consumption of seeds harvested during the previous year. Eight months after harvest there were no dormant seeds in tall fescue and red fescue seeds harvested with the moisture content of $45 \%$ and dried at the temperatures ranging from $50^{\circ} \mathrm{C}$ to $70^{\circ} \mathrm{C}$. However, maximum germination was only 79\% (tall fescue) and 74\% (red fescue), because drying temperatures caused the reduction of both, germination and dormancy. On the other hand, cocksfoot seeds harvested with the moisture content of $45 \%$ and dried at the temperatures ranging from $50^{\circ} \mathrm{C}$ to $70^{\circ} \mathrm{C}$ had germination of $81 \%$, which points out that this species is less susceptible to higher drying temperatures. Nevertheless, seeds of both cocksfoot and species of the genus Fescue harvested with a lower percentage of the 
moisture content and dried at lower temperatures are more favourable for this sowing period. Eight months after harvest the highest germination was recorded in seeds of tall fescue (96\%) and red fescue (95\%) harvested with the moisture content of $25 \%$ and dried at temperatures of $40^{\circ} \mathrm{C}$ and $50^{\circ} \mathrm{C}$, respectively. Similar results were obtained in seeds of meadow fescue (Festuca pratensis Huds.) (Stanisavljević et al., 2013). Nonetheless, the highest germination $(92 \%)$ in cocksfoot eight months after harvest was determined in seeds harvested with the moisture content of $35 \%$ and dried at the temperature of $40^{\circ} \mathrm{C}$. Furthermore, seeds harvested with the moisture content of $25 \%$ and conventionally dried $\left(22^{\circ} \mathrm{C}\right)$ retained dormancy, especially cocksfoot seeds, even after eight months, which presents a potential increase in germination for the succeeding sowing period.

A period of fourteen months after harvest coincides with the period of autumn sowing in the succeeding year. Seeds dried at $70^{\circ} \mathrm{C}$, regardless of the moisture content at harvest, continued to lose germination and none of the species had minimum germination necessary to move seeds into trade $(75 \%$ according to legislation). This also refers to seeds of all three species harvested with the moisture content of $45 \%$ and dried at $60^{\circ} \mathrm{C}$. In the case when seeds were harvested with the moisture content of $35 \%$ and dried at $60^{\circ} \mathrm{C}$, seeds of cocksfoot and tall fescue had a commercial $(80 \%)$ and limiting (75\%) value, respectively, while red fescue seeds lost commercial value $(66 \%)$. Generally, seeds of tall fescue and red fescue harvested with the moisture content of $25 \%$ and dried at $22{ }^{\circ} \mathrm{C}$ (germination $92 \%$ and $78 \%$, respectively) and seeds of cocksfoot harvested with the moisture content of $25 \%$ and dried at $30^{\circ} \mathrm{C}$ (germination $95 \%$ ) were the most favourable for autumn sowing in the year after harvest.

A high percentage and uniformity of germination with strong vigour of seedlings are an important prerequisite for a successful establishment, rapid initial growth and lucrative production in agriculture (Perry, 1980). The obtained results show that high seed germination is accompanied with strong seedling vigour, which is in accordance with previously gained results on these and other species (Stanisavljević et al., 2010 a; 2011). Tall fescue, red fescue and cocksfoot are mainly grown in the mixture with other grasses and fodder legumes. Therefore, strong seedling vigour provides successful competition with other species during crop establishment and in concurrence with other factors (growing practices, agroecological conditions) provides predicted maintenance of species within the mixture during a long-term utilisation.

\section{Conclusion}

Regardless of seed moisture contents, the drying temperature of $70^{\circ} \mathrm{C}$ reduced seed germination and accelerated deterioration over time. Drying of seeds with the moisture content of $45 \%$ at the temperature of $60^{\circ} \mathrm{C}$ was unfavourable, especially after eight and fourteen months, while dormancy was broken and satisfactory germination was obtained in seeds with the moisture content of $35 \%$ and $25 \%$. However, best germination in all three species was determined eight months after harvest of seeds with the moisture content of $25 \%$ and dried at temperatures up to $50^{\circ} \mathrm{C}$. If it is necessary to harvest seeds with greater moisture content $(45 \%)$ in order to prevent shedding, drying at the temperature ranging from $40^{\circ} \mathrm{C}$ to $50^{\circ} \mathrm{C}$ could provide satisfactory germination (80-84\%) three months after harvest of all three species. In order to preserve as long as possible the commercial value (germination $\geq 75 \%$ ) of seeds harvested with the moisture content of $45 \%$, drying temperatures should be lower (ranging from $22^{\circ} \mathrm{C}$ to $30^{\circ} \mathrm{C}$ ).

\section{Acknowledgements}

This study is a result of research within the project TR31057 supported by the Ministry of Education, Science and Technology of the Republic of Serbia.

Received 28052013

Accepted 28102013

\section{References}

Adkins S. W., Bellairs S. M., Loch D. S. 2002. Seed dormancy mechanisms in warm season grass species. Euphytica. 126 (3): 13-20 http://dx.doi.org/10.1023/A:1019623706427

Annicchiarico P., Pecetti L., Bouzerzour H., Kallida R., Khedim A., Porqueddu, C., Simoes M., Volaire F., Lelievre F. 2011. Adaptation of contrasting cocksfoot plant types to agricultural environments across the Mediterranean basin. Environmental and Experimental Botanv. 74: 82-89 http://dx.doi.org/10.1016/j.envexpbot.2011.05.002

Bewley J. D., Black M. 1994. Seeds: physiology of development and germination. New York, USA

Boyce K. G., Cole D. F., Chilcote D. O. 1976. Effect of temperature and dormancy on germination of tall fescue. Crop Science. 16 (1): 15-18 http://dx.doi.org/10.2135/cro psci1976.0011183X001600010004x

Dodig D., Zorić M., Knežević D., King S. R., ŠurlanMomirović G. 2008. Genotype × environment interaction for wheat yield in different drought stress conditions and agronomic traits suitable for selection. Australian Journal of Agricultural Research. 59 (6): 536-545 http://dx.doi.org/10.1071/AR07281

Huyghe C. 2010. Grasslands and forage crops in Europe: context and stakes. Consequences for breeding. Biotechnology in Animal Husbandry, 26 (spec. issue): 1-18

ISTA 2011. International rules for seed testing. International Seed Testing Association. Zurich, Austria, p. 1-45

Jensen T. M. 2010. Seed production in Europe with special focus on Denmark. Biotechnology in Animal Husbandry, 26 (spec. iss.): $149-158$

Kanapeckas J., Lemežienė N., Butkutė B., Stukonis V. 2011. Evaluation of tall fescue (Festuca arundinacea Schreb.) varieties and wild ecotypes as feedstock for biogas production. Zemdirbyste-Agriculture, 98 (2): 149-156

Martins L., Silva W. R. 2001. Dormancy performance of Brachiaria brizantha seeds submitted to thermal and chemical treatments. Pesquisa Agropecuaria Brasileira, 36 (7): 997-1003 http://dx.doi.org/10.1590/S0100-204X2001000700010

Pecetti L., Annicchiarico P., Abdelguerfi A., Kallida R., Mefti M., Porqueddu C., Simões N. M., Volaire F., Lelièvre F. 2011. Response of Mediterranean tall fescue cultivars to contrasting agricultural environments and implications for selection. Journal of Agronomy and Crop Science. 197: 12-20 http://dx.doi.org/10.1111/j.1439-037X.2010.00443.x

Perry D. A. 1980. The concept of seed vigor and its relevance to seed production techniques. Hebblathwaite P. D. (ed.). Seed production. London, UK, p. 585-591 
Probert R. J. 2000. The role of temperature in the regulation of seed dormancy and germination. Fenner M. (ed.). Seeds: the ecology of regeneration in plant communities. Wallingford, UK, p. 261-292

Rizza F., Badeckb F. W., Cattivellia L., Lidestric O., Di Fonzoc N., Stanca A. M. 2004. Use of a water stress index to identify barley genotypes adapted to rainfed and irrigated conditions. Crop Science, 44: 2127-2137 http://dx.doi.org/10.2135/cropsci2004.2127

Samuil C., Vintu V., Sirbu C., Surmei M. G. 2012. Behaviour of fodder mixtures with alfalfa in north-eastern Romania. Romanian Agricultural Research, 29: 227-235

Stanisavljević R., Dragićević V., Milenković J., Djukanović L., Djokić D., Terzić D., Dodig D. 2010 (a). Effects of the duration of after-ripening period on seed germinations and seedling size in three fescue species. Spanish Journal of Agricultural Research, 8 (2): 454-459 http://dx.doi.org/10.5424/sjar/2010082-1179

Stanisavljević R., Đokić D., Milenković J., Đukanović L., Terzić D., Stevović V., Dodig D. 2010 (b). Desiccation, postharvest maturity and seed aging of tall oat-grass. Pesquisa Agropecuaria Brasileira, 45 (11): 1297-1302

Stanisavljević R., Đokić D., Milenković J., Đukanović L., Stevović V., Simić A., Dodig D. 2011. Seed germination and seedling vigour of Italian ryegrass, cocksfoot and timothy following harvest and storage. Ciencia e Agrotecnologia, 35 (6): 1141-1148

http://dx.doi.org/10.1590/S1413-70542011000600014
Stanisavljević R., Vučković S., Simić A., Marković J., Lakić Ž., Terzić D., Đokić D. 2012. Acid and temperature treatments result in increased germination of seeds of three fescue species. Notulae Botanicae Horti Agrobotanici, 40 (2): 220-226

Stanisavljević R., Milenković J., Djokić D., Terzić D., Petrović D., Djukanović L., Dodig D. 2013. Drying of meadow fescue seeds of different moisture contents: changes in dormancy and germination. Plant Soil and Environment, 59 (1): 37-43

Sudarić A., Simić D., Vratarić M., 2006. Characterization of genotype by environment interactions in soybean breeding programmes of southeast Europe. Plant Breeding, 125 (2): 191-194 http://dx.doi.org/10.1111/j.1439-0523.2006.01185.x

Sveinsson T., Björnsson H. 1994. The effect of seed maturity, drying temperature, and storage temperature on germination and viability in Icelandic Poa pratensis L. Icelandic Agricultural Science, 8: 59-71

Šlepetys J. 2001. Changes in the chemical composition of grass seed and stem during the period of ripening. Biologija, 2: $57-61$

Tilvikienė V., Venslauskas K., Navickas K., Župerka V., Dabkevičius Z., Kadžiulienė Ž. 2012. The biomass and biogas productivity of perennial grasses. ZemdirbysteAgriculture, 99 (1): 17-22

ISSN 1392-3196 / e-ISSN 2335-8947

Zemdirbyste-Agriculture, vol. 101, No. 2 (2014), p. 169-176

DOI 10.13080/z-a.2014.101.022

\title{
Skirtingos brandos nuimtų pašarinių žolių sẻklų džiovinimas ir daigumo kitimas saugojimo metu
}

\author{
R. Stanisavljević1, D. Djokić2 , J. Milenković2 , D. Terzić2 , V. Stevović3 , D. Tomić3 , D. Dodig ${ }^{4}$ \\ ${ }^{1}$ Serbijos augalu apsaugos ir aplinkos institutas \\ ${ }^{2}$ Serbijos pašarinių augalų institutas \\ ${ }^{3}$ Kragujevac universitetas, Serbija \\ ${ }^{4}$ Zemun Polje kukurūzų tyrimų institutas, Serbija
}

\section{Santrauka}

Nendrinis eraičinas (Festuca arundinacea Schreb.), raudonasis eraičinas (Festuca rubra L.) ir paprastoji šunažolè (Dactylis glomerata L.) yra svarbios pašarinès žolès, tačiau jas auginant sėklai, yra linkusios byrèti ir todėl patiriami derliaus nuostoliai. Paprastai šių žolių sẻklos yra nuimamos joms pasiekus 20-35\% drègnị ir yra papildomai džiovinamos iki $12 \%$ ar mažesnio drégnio. Tačiau, siekiant išvengti byrëjimo, sẻklos buvo nuimtos $45 \%$ drègnio. Šio tyrimo metu buvo nustatyta $70,60,50,40,30$ ir $22{ }^{\circ} \mathrm{C}$ džiovinimo temperatūrų įtaka nendrinių bei raudonujų eraičinų ir paprastųjų šunažolių sẻklų daigumui ir ramybės būklei, kai sẻklos buvo nuimtos 45, 35 ir $25 \%$ drègnio. Analizès buvo atliktos iš karto išdžiovinus sẻklas - po trijų, aštuonių ir keturiolikos mènesių; tai atitinka rudeninès ir pavasarinès sėjos laiką kontinentinèje Centrinėje ir Pietryčių Europoje. Visų trijų žolių rūšių sėklų daigumą $70{ }^{\circ} \mathrm{C}$ džiovinimo temperatūra sumažino, nepriklausomai nuo sèklų drègnio, o $60{ }^{\circ} \mathrm{C}$ džiovinimo temperatūra sumažino daigumą sẻklų, nuimtų $45 \%$ drègnio. Po trijų mėnesių didžiausias sẻklų daigumas buvo nustatytas nendrinių eraičinų, kai jos buvo nuimtos $25 \%$ drègnio ir išdžiovintos $50{ }^{\circ} \mathrm{C}$ temperatūroje. Be to, didžiausias raudonujjų eraičinų ir paprastųjų šunažolių sèklų daigumas buvo nustatytas, kai jos buvo nuimtos $35 \%$ drègnio ir išdžiovintos esant $50^{\circ} \mathrm{C}$ temperatūrai. Po aštuonių mènesių didžiausias nendrinių bei raudonujų eraičinų sèklų daigumas buvo nustatytas, kai jos buvo nuimtos $25 \%$ drègnio ir išdžiovintos $40-50{ }^{\circ} \mathrm{C}$ temperatūroje, o paprastosios šunažolès - kai jos buvo nuimtos $25 \%$ drègnio ir išdžiovintos esant $22-30{ }^{\circ} \mathrm{C}$ temperatūrai. Tarp sèklų daigumo ir gyvybingumo buvo nustatyta teigiama ir esminė koreliacija.

Reikšminiai žodžiai: Dactylis glomerata, daigumas ir ramybès būklè, drègmè, džiovinimo temperatūros, Festuca arundinacea, Festuca rubra. 